\title{
Investigation of Clostridium perfringens in small-scale commercial broiler flocks in Mymensingh district of Bangladesh
}

\author{
Arunima Oarin Tresha, Mohammad Arif(D), Sk Shaheenur Islam (D, A. K. M. Ziaul Haque (D), Md. Tanvir Rahman (i) and \\ S. M. Lutful KabiriD \\ Department of Microbiology and Hygiene, Bangladesh Agricultural University, Mymensingh, Bangladesh. \\ Corresponding author: S. M. Lutful Kabir, e-mail: Ikabir79@bau.edu.bd \\ Co-authors: AOT: trishabau09@gmail.com, MA: mdarif38515@bau.edu.bd, SSI: s islam73@live.com, \\ AKMZH: vetzia.2004.bd@gmail.com, MTR: tanvirahman@bau.edu.bd \\ Received: 12-06-2021, Accepted: 29-09-2021, Published online: 29-10-2021
}

doi: www.doi.org/10.14202/vetworld.2021.2809-2816 How to cite this article: Tresha AO, Arif M, Islam SS, Haque AKMZ, Rahman MT, Kabir SML (2021) Investigation of Clostridium perfringens in small-scale commercial broiler flocks in Mymensingh district of Bangladesh, Veterinary World, 14(10): 2809-2816.

\begin{abstract}
Background and Aim: Necrotic enteritis (NE) is one of the most prevalent diseases in broiler poultry caused by Clostridium perfringens connected with significant economic losses. A cross-sectional survey was conducted in Mymensingh district of Bangladesh to assess the prevalence of $C$. perfringens through toxinotyping molecular assay and confirm the risk factors for $\mathrm{NE}$, including antimicrobial-resistant (AMR) status of the isolates.

Materials and Methods: We included 40 small-scale commercial broiler farms randomly selected from two subdistricts of Mymensingh district of Bangladesh. As an individual sample, 240 cloacal swabs, and as a pooled sample, 40 drinking water, 40 workers' hand washing, 40 litter swab, and 40 feed samples were collected and evaluated by culture, biochemical, and molecular assays. A pretested semi-structured interview questionnaire was employed to capture flock-level data on risk factors from the farm owners. The flock-level data on risk factors were assessed through univariable and multivariable logistic regression analyses with $\mathrm{p}<0.05$ was considered statistically significant.
\end{abstract}

Results: Overall flock-level prevalence of $C$. perfringens was estimated to be $10.3 \%$ (95\% confidence interval [CI] 7.5 13.6\%). Litter swab (pooled) was found to be highly contaminated with C. perfringens $(25.0 \%, 95 \%$ CI: 12.7-41.2\%) followed by the cloacal swab $(10.4 \%$, 95\% CI: $6.9-15.0 \%)$ and feed sample $(5.0 \%$, 95\% CI: $0.6-16.9 \%)$. History of coccidia infection (Adjusted odds ratio $=33.01,95 \% \mathrm{CI}: 2.14-507.59, \mathrm{p}=0.01$ ) was significantly associated with flocklevel C. perfringens infection status. In this study, $78.1 \%$ isolates were found as multidrug-resistant as they demonstrated resistance to 3-5 antimicrobial agents.

Conclusion: Evidence-based control options need to be taken through the uses of prebiotics and probiotics, biosecurity, and hygienic measurement, including control of coccidia infection, is needed to lessen the NE infection and AMR related to this pathogen in small-scale commercial broiler poultry.

Keywords: antimicrobial-resistant, Bangladesh, broiler, Clostridium perfringens, necrotic enteritis, prevalence.

\section{Introduction}

Clostridium perfringens is a Gram-positive, anaerobic, spore-forming pathogen [1]. This organism is usually present in the gastrointestinal tract of animals and humans. However, its ubiquitous distribution in the environments, especially in soil, sewage, feces, and sediments which could facilitate horizontal transmission [1,2]. C. perfringens causes many diseases both in humans and animals, including gas gangrene and food poisoning in humans and necrotic enteritis (NE) in poultry species [3].

$\mathrm{NE}$ is considered to be one of the highly prevalent diseases of broiler chickens that induce a huge economic burden for poultry industry all over the

Copyright: Tresha, et al. Open Access. This article is distributed under the terms of the Creative Commons Attribution 4.0 International License (http://creativecommons.org/licenses/by/4.0/), which permits unrestricted use, distribution, and reproduction in any medium, provided you give appropriate credit to the original author(s) and the source, provide a link to the Creative Commons license, and indicate if changes were made. The Creative Commons Public Domain Dedication waiver (http://creativecommons.org/ publicdomain/zero/1.0/) applies to the data made available in this article, unless otherwise stated. world. This disease incurs an estimated economic loss between 2 and 6 billion USD per annum [4,5]. Due to the occurrence of this disease, body weight reduced by $12 \%$ and feed conversion ratio increased by $11 \%$ in comparison to the healthy flocks.

The disease can occur between 2 and 6 weeks of age in broiler birds, both in clinical and subclinical forms [6]. Most of the clinical form of NE in chicken is characterized by unexpected high mortality without any remarkable signs; however, weight loss and poor feed conversion are noticed in subclinical form [7]. Several determinants namely, non-starch polysaccharide-enriched feed (wheat and barley), presence of coccidiosis in the flock, and inclusion of fish meal protein in the poultry feed are responsible for the occurrence of $C$. perfringens infection in poultry flock [8-11].

$C$. perfringens is divided into five classes, namely, A, B, C, D, and E; of which A, C, and D have been documented to cause NE in chickens $[12,13]$. The pathogenicity of $C$. perfringens is connected with the production of several toxins, for example, alpha $(\alpha)$, beta $(\beta)$, epsilon $(\varepsilon)$, and iota (l) toxins $[14,15]$. The major infection 
in poultry is caused by type " $\mathrm{A}$ " and with a lesser extent by type " $C$ " strains of $C$. perfringens. Type " $\mathrm{A}$ " strain produces $\alpha$-toxin; however, type " $C$ " produces $\alpha$-toxin and $\beta$-toxin. The $\alpha$-toxin produced by $C$. perfringens is considered to be the major virulence factor in the pathogenesis of NE [16,17]. In addition, two new toxinotypes have been identified, namely, C. perfringens type $\mathrm{F}$ and $\mathrm{G}$. Among them, C. perfringens type $\mathrm{F}$ causes food poisoning and antibiotic-related gastroenteritis in humans. $C$. perfringens type $\mathrm{G}$ generates NetB toxin and thus causes NE in poultry [18] which have been established to play the key role in the pathogenesis of NE $[19,20]$.

In Bangladesh, small-scale commercial poultry farms contribute $50-60 \%$ poultry meat to the national demand [21] and chicken from this production system is more likely to be colonization with infectious pathogens, even C. perfringens due to lower level of biosecurity measures. A few studies were conducted in Bangladesh to explore the burden of $C$. perfringens sparsely from NE suspected chickens [22-24]. However, none of the studies employed molecular-based robust technique (polymerase chain reaction $[\mathrm{PCR}])$ and to evaluate antimicrobial susceptibility status along with confirmation of risk factors.

Therefore, this study was carried out to investigate the prevalence, risk factors, molecular detection, and antimicrobial resistance status of C. perfringens in small-scale commercial broiler farms in Mymensingh district of Bangladesh. The outcomes of this epidemiological survey highlight the control options for broiler diseases connected with this pathogen together with providing the data for public health and food safety risk assessment.

\section{Materials and Methods}

\section{Ethical approval and Informed consent}

The study was approved by the Animal Welfare and Experimentation Ethics Committee (AWEEC) of Bangladesh Agricultural University under reference no. AWEEC/BAU/2021(12). The broiler farms were chosen after discussion with the subdistrict (Upazila) livestock offices of Department of Livestock Services, Bangladesh. Verbal consent was obtained from each of the farmers during field interview data collection and subsequent poultry sampling as a substantial number of poultry farmers are illiterate and cannot read and write.

\section{Study period and location}

The study was conducted from September 2019 to May 2020. The study was conducted in two subdistricts (Mymensingh Sadar and Trishal) of Mymensingh district under a cross-sectional survey (Figure-1).

\section{Study design and location of poultry farms}

The study used 40 broiler farms that included an equal number of farms from each subdistrict. The farms were selected with an inclusion criterion of minimum flock size $>3000$ under small-scale commercial (sector three) poultry production system at a lower level of biosecurity standard with apparently healthy birds.

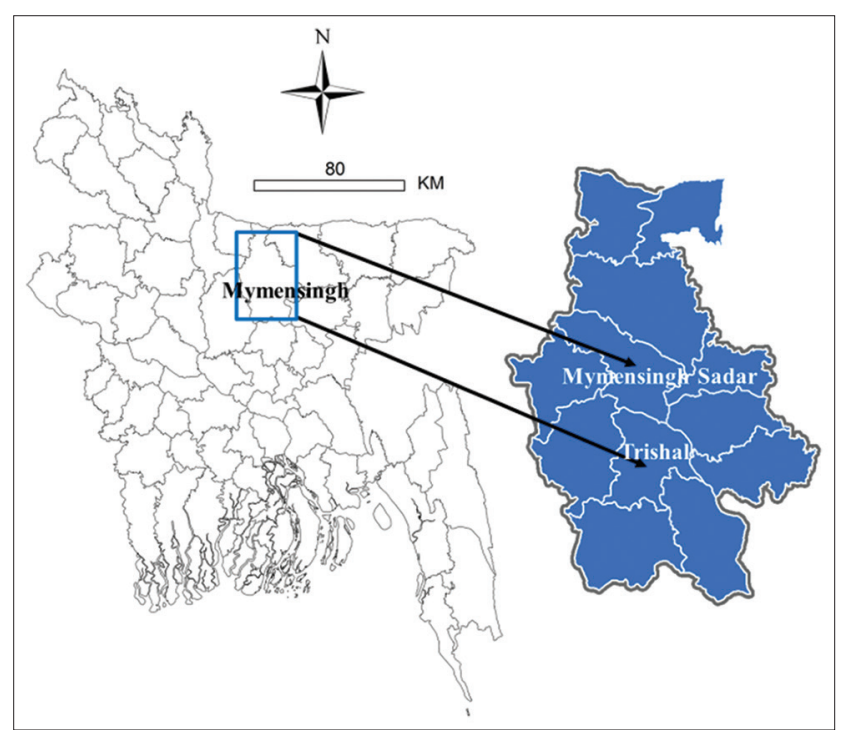

Figure-1: Locations of the surveyed farms in two subdistricts (Mymensingh Sadar and Trishal) of Mymensingh district of Bangladesh indicated by arrows on the map. The map was produced in ArcGIS-ArcMap version 10.3 (ESRI Co., Redlands, California, USA) using geographic coordinates of the study locations captured via Garmin eTrex 10. A total of 40 broiler farms were surveyed that represented equal number of farms were included from each subdistrict with a flock size $>3000$ birds under sector three production systems [Source: Map was prepared using ArcGIS-ArcMap software version 10.3].

\section{Sample collection and shipment}

An equal number of samples (both environmental and individual poultry samples) were randomly collected from each broiler farm. All samples collected from each farm were recorded in a sample collection checklist. A total of 10 samples were collected from each farm, of which, six samples were collected as environmental samples (drinking water $[\mathrm{n}=1]$, feed $[\mathrm{n}=1]$, workers handwashing $[\mathrm{n}=1]$, and litter swab $[\mathrm{n}=1]$ ) and six cloacal swab samples (single cloacal swab from each bird) were collected from each apparently healthy flock. As an environmental sample, three samples were collected from each farm and pooled together as an environmental sample for the category. The amount of samples was varied according to the category of samples as $200 \mathrm{~mL}$ water, $100 \mathrm{~g}$ feed, $200 \mathrm{~mL}$ workers hand washing, and 1-5 mL or $\mathrm{mg}$ litter/cloacal swab materials. The swab samples were preserved in normal saline. All samples were retained in sterile zipper bags and labeled with a unique identification code. The samples were transported to the designated laboratory with maintaining a cool chain as early as possible after collection $\left(4-6^{\circ} \mathrm{C}\right)$.

\section{Isolation and Identification}

\section{Culture and biochemical tests}

The samples were processed immediately after arrival at the designated laboratory as per the standard method [25]. Isolation and identification of C. perfringens were accomplished as per the protocol described earlier [26]. In brief, initial enrichment was made using the processed sample in Robertson's Cooked 
Meat media (RCM broth), (HiMedia, Mumbai, India), subsequently, anaerobic incubation at $37^{\circ} \mathrm{C}$ for $24 \mathrm{~h}$ through candle jar method. The existence of turbidity in the incubated broth media implies presence of anaerobic bacteria. A loopful of positive culture was streaked on perfringens agar base (TSC; HiMedia, India) with selective supplement (HiMedia) and incubated in the anaerobic jar at $37^{\circ} \mathrm{C}$ for $24 \mathrm{~h}$. Successively, cultured plates were observed for the growth of $C$. perfringens and colony morphology was evaluated and recorded concurrently. Gram's staining, motility test through hanging drop method, and biochemical tests such as catalase and oxidase tests were accomplished as per standard protocol [27]. Thus, obtained pure colonies were used in the molecular evaluation.

\section{Molecular detection}

In this evaluation, DNA was extracted from the pure bacterial culture by boiling method as previously described [28-30]. In brief, a loopful of bacterial colonies was taken and suspended in $1.5 \mathrm{~mL}$ microcentrifuge tubes containing $200 \mu \mathrm{L}$ distilled water by gentle vortexing and then centrifuged for $10 \mathrm{~min}$ at $14,000 \times g$. After that, the pellet was suspended in $200 \mu \mathrm{L}$ of TE buffer by gentle vortexing. Then, the microcentrifuge tubes were boiled for $15 \mathrm{~min}$ at $100^{\circ} \mathrm{C}$ and immediately chilled on ice for $10 \mathrm{~min}$. An aliquot of $50 \mu \mathrm{L}$ of the supernatant was stored as the DNA template for PCR. PCR amplification was carried out to detect toxin typing (alpha, beta, epsilon, and iota toxin genes of C. perfringens through multiplex reaction). Specific oligonucleotide primer sequences and corresponding to alpha, beta, epsilon, and iota toxin genes of $C$. perfringens were used in this study [14]. The list of primers with thermal conditions utilized in PCR is shown in Table-1.

The PCR assay was accomplished using a thermal cycler (Thermo Cycler, ASTEC, Japan) following the protocols described earlier [31]. Each multiplex PCR reaction mix (for alpha, beta, epsilon, and iota toxins) contained $8 \mu \mathrm{L}$ of extracted DNA template from bacterial cultures, $25 \mu \mathrm{L}$ PCR master mix (Promega, USA), $1 \mu \mathrm{L}$ of each alpha, beta, epsilon, and iota forward and reverse primers $(20 \mathrm{pmol} / \mu \mathrm{L})$, and $9 \mu \mathrm{l}$ of PCR-grade water, to form a total volume of $50 \mu \mathrm{L}$ in a PCR tube for amplification.
The PCR products were pictured in gel electrophoresis (1.5-2\% agarose, Invitrogen, Carlsbad, CA, USA), and further, colored with ethidium bromide $(0.5 \mathrm{~g} / \mathrm{mL})$ and decolored with distilled water, $10 \mathrm{~min}$ for each step, before gel images were taken using an ultraviolet transilluminator (Biometra, Göttingen, Germany).

\section{Antimicrobial susceptibility testing}

All strains of $C$. perfringens were evaluated against seven commercially available antimicrobials in Bangladesh, such as amoxicillin (AMX $30 \mu \mathrm{g}$ ), ciprofloxacin (CIP $5 \mu \mathrm{g}$ ), chloramphenicol (CHL $30 \mu \mathrm{g}$ ), erythromycin (ERY $15 \mu \mathrm{g}$ ), gentamicin (GEN $10 \mu \mathrm{g}$ ), oxytetracycline (OTE $30 \mu \mathrm{g}$ ), and ceftriaxone (CRO $30 \mu \mathrm{g}$ ) (HiMedia) through disk diffusion method. The zones of growth inhibition connected with the zone diameter were interpreted as per standards as labeled by the Clinical and Laboratory Standard Institute [32], and therefore, concluded as susceptible (S), intermediate resistant (I), or resistant (R) to the tested antimicrobial. Escherichia coli strain ATCC 25922 was used as a quality control organism. In this assessment, all interpretations were confirmed by the completion of at least two duplicates of the disk diffusion test.

\section{Data collection on risk factors}

A pretested semi-structured questionnaire was developed in English containing 15 closed-ended questions. The questionnaire mainly focused on farm management and biosecurity-related parameters. The questionnaire was translated into local language so that the farmers can easily understand its content. Two expert veterinarians and one trained enumerator were involved at face-to-face interview data collection process.

\section{Data management and statistical analyses}

The data for laboratory test and interview data were taken in hard copies and further recorded in Microsoft Excel ${ }^{\circledR}$ spreadsheets. Data were imported into Epi Info 7 program (Centers for Disease Control and Prevention, Georgia, USA) [33] for statistical analysis. The categorical data were shown as frequencies and proportion, and 95\% binomial confidence intervals (CIs) were confirmed using the Excel data analysis tool pack. The odds ratio (OR) was calculated through a univariate logistic regression model for estimating the relationship on flock level $C$. perfringens

Table-1: The list of primers with thermal conditions used in this study.

\begin{tabular}{|c|c|c|c|c|c|c|c|}
\hline \multirow[t]{2}{*}{ Primer } & \multirow[t]{2}{*}{ Sequence $\left(5^{\prime}-3^{\prime}\right)$} & \multirow[t]{2}{*}{ Target } & \multirow{2}{*}{$\begin{array}{l}\text { Amplicon } \\
\text { size }\end{array}$} & \multicolumn{3}{|c|}{ PCR condition ( 35 cycles) } & \multirow[t]{2}{*}{ Reference } \\
\hline & & & & Denature & Annealing & Extension & \\
\hline \multirow{3}{*}{$\begin{array}{l}\text { Cpa-F } \\
\text { Cpa-R } \\
\text { Cpb-F } \\
\text { Cpb-R }\end{array}$} & $\begin{array}{l}\text { GTTGATAGCGCAGGACATGTTAAG } \\
\text { CATGTAGTCATCTGTTCCAGCATC }\end{array}$ & cpa (Alpha toxin) & 402 bp & $94^{\circ} \mathrm{C}, 30 \mathrm{~s}$ & $59^{\circ} \mathrm{C}, 45 \mathrm{~s}$ & $72^{\circ} \mathrm{C}, 45 \mathrm{~s}$ & \multirow[t]{3}{*}{ [14] } \\
\hline & ACTATACAGACAGATCATTCAACC & \multirow{2}{*}{$c p b$ (Beta toxin) } & \multirow[t]{2}{*}{236 bp } & \multirow[t]{2}{*}{$94^{\circ} \mathrm{C}, 30 \mathrm{~s}$} & \multirow[t]{2}{*}{$59^{\circ} \mathrm{C}, 45 \mathrm{~s}$} & \multirow{2}{*}{$72^{\circ} \mathrm{C}, 45 \mathrm{~s}$} & \\
\hline & TTAGGAGCAGTTAGAACTACAGAC & & & & & & \\
\hline \multirow{2}{*}{$\begin{array}{l}\text { Etx-F } \\
\text { Etx-R }\end{array}$} & ACTGCAACTACTACTCATACTGTG & \multirow{2}{*}{$\begin{array}{l}\text { Etx (Epsilon } \\
\text { toxin) }\end{array}$} & \multirow[t]{2}{*}{$541 \mathrm{bp}$} & \multirow[t]{2}{*}{$94^{\circ} \mathrm{C}, 30 \mathrm{~s}$} & \multirow[t]{2}{*}{$59^{\circ} \mathrm{C}, 45 \mathrm{~s}$} & \multirow[t]{2}{*}{$72^{\circ} \mathrm{C}, 45 \mathrm{~s}$} & \\
\hline & CTGGTGCCTTAATAGAAAGACTCC & & & & & & \\
\hline Cpi-F & GCGATGAAAAGCCTACACCACTAC & \multirow{2}{*}{ cpi (Iota toxin) } & \multirow[t]{2}{*}{317 bp } & \multirow[t]{2}{*}{$94^{\circ} \mathrm{C}, 30 \mathrm{~s}$} & \multirow{2}{*}{$59^{\circ} \mathrm{C}, 45 \mathrm{~s}$} & \multirow[t]{2}{*}{$72^{\circ} \mathrm{C}, 45 \mathrm{~s}$} & \\
\hline Cpi-R & GGTATATCCTCCACGCATATAGTC & & & & & & \\
\hline
\end{tabular}

$\mathrm{PCR}=$ Polymerase chain reaction 
positive status, and $\mathrm{p}<0.05$ was was considered statistically significant, finally, significant variables were included in the multivariable logistic regression analysis.

\section{Results}

Prevalence of $C$. perfringens

The survey evaluated an overall prevalence of C. perfringens as $10.3 \%(95 \% \mathrm{CI}: 7.5-13.6)$, including all categories of samples through culture, biochemical tests, and finally, toxinotyping molecular detection. Among the environment samples, litter swab was found to be highly contaminated with C. perfringens $(25.0 \%, 95 \%$ CI: $12.7-41.2)$ followed by worker's handwashing and poultry feed, respectively. However, a prevalence of $10.4 \%$ (95\% CI: $6.9-15.0)$ was estimated in poultry swab samples. The distribution of prevalence in different samples was found to be statistically significant $(\mathrm{p}=0.004)$ (Table-2). Of 40 farms, 24 were found contaminated with C. perfringens; therefore, $60 \%$ (95\% CI: 43.3\%-75.1) prevalence was observed at the farm level.

\section{Molecular detection of the isolates}

All 41 isolates were utilized in toxinotyping $c p a, c p b$, etx, and cpi gene-based multiplex PCR and found positive only for $c p a$ as they demonstrated $402 \mathrm{bp}$ amplicon of alpha-toxin gene (cpa gene) of $C$. perfringens (Figure-2). Thus, isolates were confirmed as toxinotype A. None of the isolates carried $c p b$, etx, or $c p i$ genes and demonstrated the absence of $C$. perfringens toxinotype $\mathrm{B}, \mathrm{C}, \mathrm{D}$, or $\mathrm{E}$ in positive samples.

\section{Risk factors assessment}

A total of 15 parameters regarding farm management, biosecurity practices were used in univariable analysis. In this analysis, three variables such as age of the birds (weeks), history of coccidia infection, and litter type were significantly related with the flock-level C. perfringens positive status. The rest of the factors were found to be non-significant with the flock-level outcome status (Table-3).

Among the risk factors, three were included in the multivariable mixed-effect logistic regression analysis as these were captured to be statistically significant in univariable analysis. The potential risk factors for flock-level C. perfringens were identified in this final model. The most important risk factor connected with the flock-level $C$. perfringens infection was identified as "history of coccidia infection in the flock" (Table-4). The likelihood of C. perfringens infection was found 33.01 times (95\% CI: 2.14$507.59, \mathrm{p}=0.01$ ) higher in broiler farms with the history of coccidia infection.

\section{Antibiogram}

Antimicrobial susceptibility pattern

In this assessment, of 41 isolates of $C$. perfringens, $92.7 \%(\mathrm{n}=38)$ were documented $\mathrm{S}$ to CIP, followed by CRO $(85.4 \%, n=35$ AMX $(70.7 \%, n=29)$, CHL $(36.6 \%, n=15)$, respectively. However, $29.3 \%$ $(\mathrm{n}=12)$ isolates were revealed intermediate $\mathrm{S}$ to OTE ( $29.3 \%, \mathrm{n}=12)$, followed by CHL $(22.0 \%, \mathrm{n}=9)$, AMX $(14.6 \%, n=6)$, and CIP and/or ERY $(7.3 \%, n=3)$, respectively. Alarmingly, no isolates $(0 \%, \mathrm{n}=0)$ was captured as S or I-S to GEN (Table-5).

\section{Antimicrobial-resistance (AMR) status}

Among the 41 isolates of C. perfringens, $7.3 \%$ $(\mathrm{n}=3)$ and $14.6 \%(\mathrm{n}=6)$ were demonstrated resistance to two antimicrobial agents, GEN-OTE and GENERY, respectively. However, 41.5\% ( $\mathrm{n}=17)$ were shown $\mathrm{R}$ to three antimicrobial agents (GEN-ERYOTE). Alarmingly, $22.0 \%(n=9)$ and $7.3 \%(n=3)$ of isolates were captured $\mathrm{R}$ to four antimicrobial agents, CHL-ERY-GEN-OTE and AMX-ERY-GEN-OTE, respectively, and $7.3 \%(n=3)$ to five antimicrobial agents (AMX-CHL-ERY-GEN-OTE) (Figure-3).

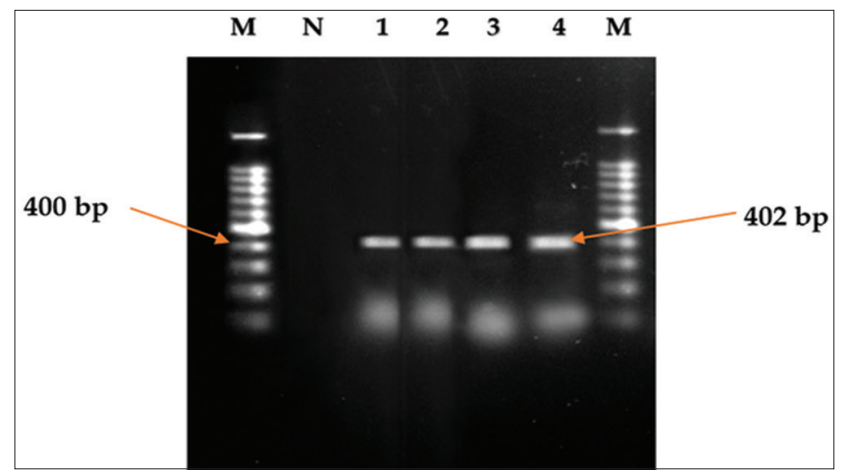

Figure-2: Agarose gel electrophoresis showing 402 bp amplicon of alpha-toxin gene (cpa gene) of Clostridium perfringens [14]. Lane M: 100 bp DNA marker; lane $\mathrm{N}$ : Negative control; lanes 1-4: Isolates positive for C. perfringens.

Table-2: Prevalence of $C$. perfringens in broiler farms of Mymensingh district of Bangladesh.

\begin{tabular}{lccc}
\hline Sample category & Number of samples tested & Number of positive sample Prevalence (95\% CI) $\mathbf{p - v a l u e ~}$ \\
\hline Environmental samples & 40 & 0 & $0.0(0.0-8.8)$ \\
$\quad$ Drinking water & 40 & 4 & $10.0(2.8-23.7)$ \\
Worker's hand washing & 40 & 10 & $25.0(12.7-41.2)$ \\
Litter swab & 40 & 2 & $5.0(0.6-17.0)$ \\
Feed & & 25 & $10.4(6.9-15.0)$ \\
Poultry samples & 240 & 41 & $10.3(7.5-13.6)$ \\
$\quad$ Cloacal swab & 400 & & \\
Overall & &
\end{tabular}

C. perfringens $=$ Clostridium perfringens 
Table-3: Result from univariable logistic regression analysis displaying the relationship with farm level $C$. perfringens infection in 40 broiler farms.

\begin{tabular}{|c|c|c|c|c|}
\hline Variables & Category & Positive (\%) & Odds ratio & p-value \\
\hline Age of the birds (weeks) & $\begin{array}{l}1-3 \text { weeks }(n=24) \\
3-4 \text { weeks }(n=16)\end{array}$ & $\begin{array}{l}18(75.0) \\
6(37.5)\end{array}$ & $\begin{array}{c}\text { Reference } \\
5.0(1.3-19.7)\end{array}$ & 0.04 \\
\hline \multirow[t]{2}{*}{ History of coccidia infection } & Yes $(n=19)$ & $18(94.7)$ & $45(4.9-416.5)$ & 0.000 \\
\hline & $\begin{array}{l}\text { No }(n=21) \\
\text { Throw elsewhere }(n=31)\end{array}$ & $\begin{array}{c}6(28.6) \\
18(58.1)\end{array}$ & $\begin{array}{c}\text { Reference } \\
1.4(0.3-6.8)\end{array}$ & 0.64 \\
\hline Disposal of dead birds & Burial $(n=9)$ & $6(66.7)$ & Reference & \\
\hline \multirow[t]{2}{*}{ Feeder and drinker wash daily } & Yes $(n=14)$ & $8(57.1)$ & Reference & 0.78 \\
\hline & No $(n=26)$ & $16(66.7)$ & $1.2(0.3-4.5)$ & \\
\hline \multirow[t]{2}{*}{ Clean interval of litter } & $1 /$ week $(n=30)$ & $16(66.7)$ & $0.8(0.5-1.1)$ & 0.13 \\
\hline & $2 /$ week $(n=10)$ & $8(80.0)$ & Reference & \\
\hline \multirow[t]{2}{*}{ Litter type } & Wet $(n=15)$ & $13(86.7)$ & $8.3(1.5-44.6)$ & 0.007 \\
\hline & Dry $(n=25)$ & $11(44.0)$ & Reference & \\
\hline \multirow[t]{2}{*}{ Stocking density } & 1 Sq. feet/bird $(n=9)$ & $4(44.4)$ & $0.4(0.09-2.0)$ & 0.30 \\
\hline & $>1$ Sq. feet/bird $(n=31)$ & $20(83.3)$ & Reference & \\
\hline Waste disposal of poultry farm & $\begin{array}{l}\text { Within } 10 m \text { of } \operatorname{far}(n=38) \\
>10 m \text { of the farm }(n=2)\end{array}$ & $\begin{array}{l}23(60.5) \\
1(50.0)\end{array}$ & $\begin{array}{l}1.5(0.1-26.4) \\
\text { Reference }\end{array}$ & 0.76 \\
\hline
\end{tabular}

C. perfringens $=$ Clostridium perfringens

Table-4: Factors retained in the final multivariable mixed-effect logistic regression model of risk of flock level C. perfringens infection.

\begin{tabular}{lccccccc}
\hline Determinates & Category & AOR & $\mathbf{9 5 \%}$ CI & Coefficient & SE & Z-statistic & p-value \\
\hline Age of the bird (weeks) & $1-3$ & 1.61 & $0.27-9.69$ & 0.47 & 0.91 & 0.521 & 0.60 \\
History of coccidia infection in the flock & $\begin{array}{l}\text { Yes } \\
\text { Yes }\end{array}$ & 33.01 & $2.14-507.59$ & 3.49 & 1.39 & 2.5083 & 0.01 \\
Litter condition & $\begin{array}{l}\text { No } \\
\text { Wet } \\
\text { Dry }\end{array}$ & 1.21 & $0.09-15.17$ & 0.19 & 1.287 & 0.1525 & 0.87 \\
& & & & & & \\
\hline
\end{tabular}

$\mathrm{AOR}=$ Adjusted odds ratio, $\mathrm{CI}$ : Confidence interval, $\mathrm{SE}=$ Standard error. $\mathrm{C}$. perfringens=Clostridium perfringens

Table-5: Antimicrobial susceptibility status of C. perfringens isolates from 40 broiler flocks.

\begin{tabular}{lccc}
\hline Antimicrobial agents & \multicolumn{3}{c}{ Isolates } \\
\cline { 2 - 4 } & Resistant \% (n) & Intermediate \% (n) & Susceptible \% (n) \\
\hline Amoxicillin $(30 \mu \mathrm{g})$ & $14.6(6)$ & $14.6(6)$ & $70.7(29)$ \\
Chloramphenicol $(30 \mu \mathrm{g})$ & $41.5(17)$ & $22.0(9)$ & $36.6(15)$ \\
Ciprofloxacin $(5 \mu \mathrm{g})$ & $0.0(0)$ & $7.3(3)$ & $92.7(38)$ \\
Erythromycin $(15 \mu \mathrm{g})$ & $92.7(38)$ & $7.3(3)$ & $0.0(0)$ \\
Gentamicin $(10 \mu \mathrm{g})$ & $100.0(41)$ & $0.0(0)$ & $0.0(0)$ \\
Oxytetracycline $(30 \mu \mathrm{g})$ & $70.7(29)$ & $29.3(12)$ & $0.0(0)$ \\
Ceftriaxone $(30 \mu \mathrm{g})$ & $0.0(0)$ & $14.6(6)$ & $85.4(35)$ \\
\hline
\end{tabular}

C. perfringens $=$ Clostridium perfringens

\section{Discussion}

We evaluated prevalence, risk factors, molecular confirmation though toxinotyping gene andAMR pattern of $C$. perfringens isolated from small-scale commercial broiler flocks of a promising poultry rearing district of Bangladesh. In this survey, we evaluated $C$. perfringens in apparently healthy flocks through $\alpha$-toxin gene-targeted primers. Thus, 41 isolates were established for $c p a$ gene (402 bp) that signifies $C$. perfringens type $\mathrm{A}$ in the broiler samples. These PCR assays were also reported to be utilized by other researchers in India [28,31].

C. perfringens was found to be prevalent in $60 \%$ farms $(24 / 40)$ with a sample level prevalence was documented as $10.3 \%(41 / 400)$ in apparently healthy flocks. These results can be elucidated by the view as a commensal organism, C. perfringens is living in the gastrointestinal tract of humans and animals [7,34]. In general, healthy birds have $C$. perfringens below $10^{5} \mathrm{CFU} /$ gram intestinal content. Nevertheless, the increase in the number of $C$. perfringens between $10^{7}$ and $10^{9} \mathrm{CFU} / \mathrm{gram}$ intestinal content has been confirmed NE outbreaks in healthy poultry flocks [35].

This finding of this study is consistent with the similar study conducted in Tamil Nadu, India, as $10.76 \%$ prevalence of $C$. perfringens was confirmed in livestock and poultry specimens [36]. Other studies conducted in India captured higher prevalence 


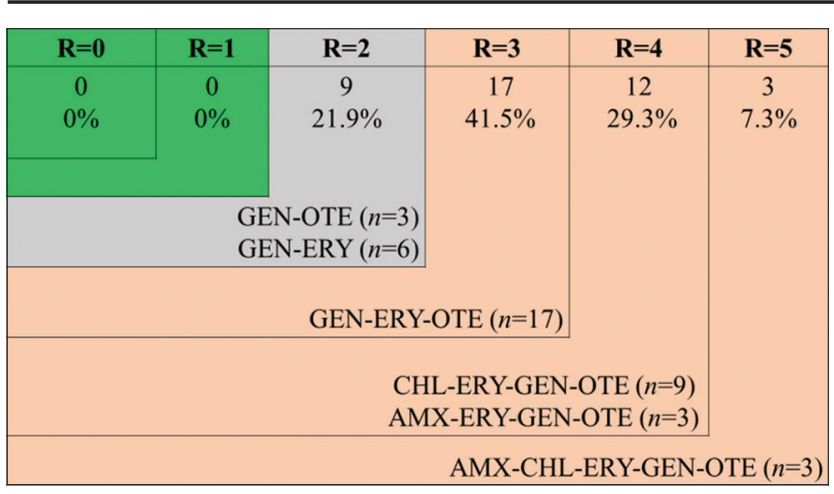

Figure-3: Distribution of antimicrobial resistance status for Clostridium perfringens $(n=41)$ strains isolated from broiler farms, $\mathrm{R}=$ Number of antibiotic resistances; $\mathrm{AMX}=$ Amoxicillin, $\mathrm{CHL}=$ Chloramphenicol, $\mathrm{ERY}=$ Erythromycin, OTE=Oxytetracycline, GEN=Gentamicin, $n=$ Number of isolates with the indicated pattern.

as $33.89 \%$ in poultry feed samples in Tamil Nadu, South India [37], 33.63\% and $18.91 \%$ in broiler of 2-6 weeks age and older layer, respectively, in Kashmir, India [38], and 53\% dead broilers in West Bengal, India [39]. The prevalence that was established from this study is comparatively lower than the earlier studies conducted in different geographical locations $48.82 \%$ [40] and $23.1 \%$ [41] in China; $29.6 \%$ in Taiwan [42]; $57.9 \%$ in Egypt [29]; and $24.72 \%$ and $23.28 \%$ from two commercial poultry farms in Canada [43]. However, we could not compare our study findings in a country context due to the lack of reference data of NE in broiler chicken using the advance molecular assay. There are several studies conducted in Bangladesh that have confirmed the prevalence of $C$. perfringens between $0.4 \%$ to $1 \%$ based on history, clinical findings, including postmortem lesions [22-24].

The crude relationship between flock-level risk factors and $C$. perfringens-positive status was age of the birds (3-4 weeks), history of coccidia infection, and litter type (wet). The age of birds (3-4 weeks) $(\mathrm{OR}=5.0$, 95\% CI: 1.3-19.7, $\mathrm{p}=0.04)$ and wet litter $(\mathrm{OR}=8.3$, 95\% CI: $1.5-44.6, \mathrm{p}=0.007$ ) were found to be more likely with $C$. perfringens infection in broiler flocks. Similarly, history of coccidian infection $(\mathrm{OR}=45,95 \%$ CI: 4.9-416.5, $\mathrm{p}=0.000)$ and wet litter $(\mathrm{OR}=8.3,95$ CI: $1.5-44.6, \mathrm{p}=0.007)$ have more likelihood with the farm level C. perfringens infection. The association of the occurrence of $C$. perfringens with the age group (3-4 weeks) has been confirmed by another study in Egypt [29]. Similarly, litter conditions can play an important role for NE occurrence in the poultry flock, which is supported by another study [44]. However, in the final multivariable logistic model, history of coccidia infection (adjusted OR $=33.01,95 \%$ CI: 2.14$507.59, \mathrm{p}=0.01$ ) was found to be a strong association with $C$. perfringens infection in the broiler flocks. This finding is supported by other authors as the leading risk factor for NE, coccidia infection causes damage of the mucous membrane that supports to the attachment of $C$. perfringens $[8,10]$. Therefore, prevention of coccidial infection is needed to control NE outbreaks in the poultry flocks.

The antimicrobial sensitivity status in this study showed that $C$. perfringens isolates were $92.7 \%$ sensitive to CIP followed by CRO (85.4\%) and AMX (70.7\%). However, a lower level of susceptibility was detected to CHL (36.0\%). These findings are partially corroborated by other studies [26,45-47]. Alarmingly, a few antimicrobials such as ERY, gentamycin, and OTE were captured as $\mathrm{S}$ to $0.0 \%$ of isolates. This finding indicates that some antimicrobials agents such as ERY, OTE, AMX, streptomycin, CIP, norfloxacin, and azithromycin are being used frequently in broiler production in Bangladesh [48]. Bangladesh Government has enacted relevant acts and rules for prudent use of antimicrobials agents through registered veterinarians only for therapeutic purposes in animal production $[49,50]$. However, the emergence of such AMR due to unscrupulous use of certain antimicrobials agents as growth promoters and feed additives in poultry rearing has now become a significant public health hazard $[48,51,52]$.

In this present study, $78.1 \%$ of isolates were found to be multidrug-resistant (MDR) as they demonstrated resistance against 3 to 5 (GEN-ERY-OTE, CHL-ERYGEN-OTE, AMX-ERY-GEN-OTE, and AMX-CHLERY-GEN-OTE) antimicrobial agents. This finding is sparsely supported by a study conducted in Korea as most of the isolates of $C$. perfringens identified from NE outbreaks are found to be R to commonly used antimicrobial agents such as GEN and streptomycin [53]. The phenomenon of MDR development is due to the extensive use of antimicrobial agents as growth promoters and feed additives in poultry feed to prevent Gram-positive bacteria along with C. perfringens [54]. In this regard, alternate options such as use of prebiotics and probiotics, herbs, and organic acids, including enzymes, have become more pertinent in poultry production nowadays [44].

The present survey is the first inconclusive research in Bangladesh to evaluate the prevalence, risk factors, and AMR status of $C$. perfringens in broiler flocks. The finding of this research will help in the formulation of proof-based intervention approaches to lessen the burden of $C$. perfringens in poultry, also reduce human introduction of this significant food pathogens.

\section{Limitations of the study}

The main limitation of this study is that the study was conducted only in a single district. However, some important risk factors related to feed composition (like non-starch polysaccharide-enriched feed and use of fish meal) did not consider as a risk factor as the farmers were using high standard commercial poultry feed from the reputed feed companies.

\section{Conclusion}

The study highlights the presence of MDR C. perfringens in broiler flocks and its associated burden of 
treatment failures in poultry and public health hazards. Therefore, evidence-based control options that included improvement of broiler gut health by the use of antibiotic substitutes such as prebiotics, probiotics, and organic acids, including vaccines for NE should be considered. As a part of control measures, biosecurity programs such as proper litter management, dedicated clothing and shoes, and handwashing facilities in each poultry house are needed for lessening the disease occurrence in poultry. Control of coccidia infection in the broiler flock is high demanding for curbing the infection of NE.

\section{Authors' Contributions}

SMLK: Planned and designed the study. AOT, MA, and AKMZH: Assisted in field survey and laboratory assessment. AOT and SSI: Analyzed the data and drafted the manuscript. SMLK and MTR: Assisted in review and editing of the manuscript. All authors have read and agreed to the published version of the manuscript.

\section{Acknowledgments}

The authors are grateful to the subdistrict (Upazila) and district livestock officers of Mymensingh district of Bangladesh for their cordial support to the selection of broiler farms. The authors would also like to extend their gratitude to broiler farmers/farm attendants for broiler sampling and interview data collection. The study was funded by Ministry of Science and Technology, Government of the People's Republic of Bangladesh, Bangladesh Secretariat, Dhaka-1000, Bangladesh (Project No. 2020/11/MoST).

\section{Competing Interests}

The authors declare that they have no competing interests.

\section{Publisher's Note}

Veterinary World remains neutral with regard to jurisdictional claims in published map and institutional affiliation.

\section{References}

1. Abdelrahim, A.M., Radomski, N., Delannoy, S., Djellal, S., Le Négrate, M., Hadjab, K., Fach, P., Hennekinne, J., Mistou, M. and Firmesse, O. (2019) Large-scale genomic analyses and toxinotyping of Clostridium perfringens implicated in foodborne outbreaks in France. Front. Microbiol., 10 (2019): 777.

2. Hibberd, M.C., Neumann, A.P., Rehberger, T.G. and Siragusa, G.R. (2011) Multilocus sequence typing subtypes of poultry Clostridium perfringens isolates demonstrate disease niche partitioning. J. Clin. Microbiol., 49(4): 1556-1567.

3. Guran, H.S. and Oksuztepe, G. (2013) Detection and typing of Clostridium perfringens from retail chicken meat parts. Lett. Appl. Microbiol., 57(1): 77-82.

4. Wade, B. and Keyburn, A. (2015) The true cost of necrotic enteritis. World Poult., 31(7): 16-17.

5. McReynolds, J.L., Byrd, J.A., Anderson, R.C., Moore, R.W., Edrington, T.S., Genovese, K.J., Poole, T.L., Kubena, L.F. and Nisbet, D.J. (2004) Evaluation of immunosuppressants and dietary mechanisms in an experimental disease model for necrotic enteritis. Poult. Sci., 83(12): 1948-1952.
6. Skinner, J.T., Bauer, S., Young, V., Pauling, G. and Wilson, J. (2010) An economic analysis of the impact of subclinical (mild) necrotic enteritis in broiler chickens. Avian Dis., 54(4): 1237-1240.

7. Miller, R.W., Skinner, J., Sulakvelidze, A., Mathis, G.F. and Hofacre, C.L. (2010) Bacteriophage therapy for control of necrotic enteritis of broiler chickens experimentally infected with Clostridium perfringens. Avian Dis., 54(1): 33-40.

8. Williams, R. (2005) Intercurrent coccidiosis and necrotic enteritis of chickens: Rational, integrated disease management by maintenance of gut integrity. Avian Pathol., 34(3): 159-180.

9. Collier, C., Hofacre, C., Payne, A., Anderson, D., Kaiser, P., Mackie, R.I. and Gaskins, H.R. (2008) Coccidia-induced mucogenesis promotes the onset of necrotic enteritis by supporting Clostridium perfringens growth. Vet. Immunol. Immunopathol., 122(1-2): 104-115.

10. Timbermont, L., Haesebrouck, F., Ducatelle, R. and Van Immerseel, F.V. (2011) Necrotic enteritis in broilers: An updated review on the pathogenesis. Avian Pathol., 40(4): 341-347.

11. Moore, R.J. (2016) Necrotic enteritis predisposing factors in broiler chickens. Avian Pathol., 45(3): 275-281.

12. Kalender, H., Ertas, H., Cetinkaya, B., Muz, A., Arslan, N. and Kilic, A. (2005) Typing of isolates of Clostridium perfringens from healthy and diseased sheep by multiplex PCR. Vet. Med. Czech, 50(10): 439-442.

13. Engström, B., Fermer, C., Lindberg, A., Saarinen, E., Båverud, V. and Gunnarsson, A. (2003) Molecular typing of isolates of Clostridium perfringens from healthy and diseased poultry. Vet. Microbiol., 94(3): 225-235.

14. Yoo, H.S., Lee, S.U., Park, K.Y. and Park, Y.H. (1997) Molecular typing and epidemiological survey of prevalence of Clostridium perfringens types by multiplex PCR. J. Clin. Microbiol., 35(1): 228-232.

15. Schlegel, B.J., Nowell, V.J., Parreira, V.R., Soltes, G. and Prescott, J.F. (2012) Toxin-associated and other genes in Clostridium perfringens Type A isolates from bovine clostridial abomasitis (BCA) and jejunal hemorrhage syndrome (JHS). Can. J. Vet. Res., 76(4): 248-254.

16. Fukata, T., Hadate, Y., Baba, E., Uemura, T. and Arakawa, A. (1988) Influence of Clostridium perfringens and its toxin in germ-free chickens. Res. Vet. Sci., 44(1): 68-70.

17. Al-Sheikhly, F. and Truscott, R. (1977) The interaction of Clostridium perfringens and its toxins in the production of necrotic enteritis of chickens. Avian Dis., 21(2): 256-263.

18. Rood, J.I., Adams, V., Lacey, J., Lyras, D., McClane, B.A., Melville, S.B., Moore, R.J., Popoff, M.R., Sarker, M.R., Songer, J.G., Uzal, F.A. and Immerseel, F.V. (2018) Expansion of the Clostridium perfringens toxin-based typing scheme. Anaerobe., 53(2018): 5-10.

19. Keyburn, A.L., Boyce, J.D., Vaz, P., Bannam, T.L., Ford, M.E., Parker, D., Di Rubbo, A., Rood, J.I. and Moore, R.J. (2008) NetB, a new toxin that is associated with avian necrotic enteritis caused by Clostridium perfringens. PLoS Pathog., 4(2): e26.

20. Keyburn, A.L., Yan, X.X., Bannam, T.L., Van Immerseel, F., Rood, J.I. and Moore, R.J. (2010) Association between avian necrotic enteritis and Clostridium perfringens strains expressing NetB toxin. Vet. Res., 41(2): 1-8.

21. Dolberg, F. (2008) Poultry Sector Country Review, Bangladesh. FAO Animal Production and Health Division, Food and Agriculture Organization of the United Nations, United States.

22. Hossain, M.K., Ahmed, M., Kabir, H., Sarker, M.R., Jalil, M.A. and Adhikary, G.N. (2004) Poultry diseases at Rajshahi in Bangladesh. J. Anim. Vet. Adv., 3(10): 656-658.

23. Islam, M.R., Das, B.C., Hossain, K., Lucky, N.S. and Mostafa, M.G. (2003) A study on the occurrence of poultry diseases in Sylhet region of Bangladesh. Int. J. Poult. Sci., 2(5): 354-356.

24. Talha, A.F.S., Hossain, M.M., Chowdhury, E.H., 
Bari, A.S.M., Islam, M.R. and Das, P.M. (2001) Poultry diseases occurring in Mymensingh district of Bangladesh. Bangladesh Vet., 18(1): 20-23.

25. Ezatkhah, M., Alimolaei, M. and Shahdadnejad, N. (2016) The prevalence of netB gene in isolated Clostridium perfringens from organic broiler farms suspected to necrotic enteritis. Int. J. Enteric. Pathog., 4(3): e35667.

26. Shelke, P.R., Pawade, M.M., Mhase, P.P., Mehere, P.V. and Sangle, J.D. (2018) Antibiotic sensitivity and histopathological study of Clostridium perfringens associated with necrotic enteritis in poultry. Int. J. Curr. Microbiol. App. Sci., 7(11): 3159-3166.

27. Agarwal, A., Narang, G., Rakha, N.K., Mahajan, N.K. and Sharma, A. (2009) In vitro lecithinase activity and antibiogram of Clostridium perfringens isolated from broiler chickens. Haryana Vet., 48: 81-84.

28. Nyrah, Q., Wani, S.A., Nazir, N., Rasool, S., Beigh, Q., Kashoo, Z.A., Hussain, I., Qureshi, S. and Ali, R. (2017) Clostridium perfringens Type A from broiler chicken with necrotic enteritis in Kashmir Valley. India Int. J. Curr. Microbiol. App. Sci., 6(12): 2443-2453.

29. Osman, K.M., Soliman, Y.A., Amin, Z.M.S. and Aly, M.A.K. (2012) Prevalence of Clostridium perfringens Type A isolates in commercial broiler chickens and parent broiler breeder hens in Egypt. Rev. Sci. Tech., 31(3): 931-941.

30. Croci, L., Delibato, E., Volpe, G., De Medici, D. and Palleschi, G. (2004) Comparison of PCR, electrochemical enzyme-linked immunosorbent assays, and the standard culture method for detecting Salmonella in meat products. Appl. Environ. Microbiol., 70(3): 1393-1396.

31. Merati, R., Temim, S. and Mohamed, A.A.A. (2017) Identification and characterization of Clostridium perfringens isolated from necrotic enteritis in broiler chickens in Tiaret, Western Algeria. Kafkas Univ. Vet. Fak. Derg., 23(4): 595-601.

32. Clinical and Laboratory Standards Institute. (2016) Performance Standards for Antimicrobial Susceptibility Testing. $26^{\text {th }}$ ed. Clinical and Laboratory Standards Institute supplement M100S, Wayne, PA. p1-256.

33. Centers for Disease Control and Prevention. (2016) Epi Info ${ }^{\text {TM }} 7$. User Guide. Available from: https://www.cdc.gov/ epiinfo/support/userguide.html. Retrieved on 12-05-2021.

34. Cooper, K.K., Songer, J.G. and Uzal, F.A. (2013) Diagnosing clostridial enteric disease in poultry. J. Vet. Diagn. Invest., 25(3): 314-327.

35. McDevitt, R.M., Brooker, J.D., Acamovic, T. and Sparks, N.H.C. (2006) Necrotic enteritis: A continuing challenge for the poultry industry. Worlds Poult. Sci. J., 62(2): 221-247.

36. Anju, K., Karthik, K., Divya, V., Priyadharshini, M.L.M., Sharma, R.K. and Manoharan, S. (2021) Toxinotyping and molecular characterization of antimicrobial resistance in Clostridium perfringens isolated from different sources of livestock and poultry. Anaerobe, 67: 102298.

37. Udhayavel, S., Ramasamy, G.T., Gowthaman, V., Malmarugan, S. and Senthilvel, K. (2017) Occurrence of Clostridium perfringens contamination in poultry feed ingredients: Isolation, identification and its antibiotic sensitivity pattern. Anim Nutr., 3(3): 309-312.

38. Dar, P.S., Wani, S.A., Wani, A.H., Hussain, I., Maqbool, R., Ganaie, M.Y., Kashoo, Z.A. and Qureshi, S. (2017) Isolation, identification and molecular characterization of Clostridium perfringens from poultry in Kashmir valley, India. J. Entomol. Zool. Stud., 5(5): 409-414.

39. Sarkar, M., Ray, J.P., Mukhopadhayay, S.K., Niyogi, D. and Ganguly, S. (2013) Study on Clostridium perfringens Type A infection in broilers of West Bengal, India. IIOAB J., 4(4): 1-3.
40. Xiu, L., Liu, Y., Wu, W., Chen, S., Zhong, Z. and Wang, H. (2020) Prevalence and multilocus sequence typing of Clostridium perfringens isolated from 4 duck farms in Shandong province, China. Poult Sci., 99(10): 5105-5117.

41. Fan, Y.C., Wang, C.L., Wang, C., Chen, T.C., Chou, C.H., Chou, C.H. and Tsai, H.J. (2016) Incidence and antimicrobial susceptibility to Clostridium perfringens in premarket broilers in Taiwan. Avian Dis., 60(2): 444-449.

42. Zhang, T., Zhang, W., Ai, D., Zhang, R., Lu, Q., Luo, Q. and Shao, H. (2018) Prevalence and characterization of Clostridium perfringens in broiler chickens and retail chicken meat in central China. Anaerobe, 54: 100-103.

43. Chalmers, G., Martin, S.W., Hunter, D.B., Prescott, J.F., Weber, L.J. and Boerlin, P. (2008) Genetic diversity of Clostridium perfringens isolated from healthy broiler chickens at a commercial farm. Vet. Microbiol., 127(1-2): 116-127.

44. Tsiouris, V. (2016) Poultry management: A useful tool for the control of necrotic enteritis in poultry. Avian Pathol., 45(3): 323-325.

45. Mehtaz, S., Borah, P., Sharma, R. and Chakraborty, A. (2013) Antibiogram of Clostridium perfringens isolated from animals and foods. Indian Vet. J., 90(1): 54-56.

46. Ibrahim, R.S., Ibtihal, M.M. and Soluman, A.M. (2001) Clostridial infection in chickens studying the pathogenicity and evaluation of the effect of some growth promoter on broiler performance. Assiut Vet. Med. J., 45: 253-267.

47. Algammal, A.M. and Elfeil, W.M. (2015) PCR based detection of Alpha toxin gene in Clostridium perfringens strains isolated from diseased broiler chickens. Benha Vet. Med. J., 29(2): 333-338.

48. Alam, B., Uddin, M.N., Mridha, D., Akhter, A.H.M., Islam, S.S., Haque, A.K.M. and Kabir, S.M.L. (2020) Occurrence of Campylobacter spp. in selected small scale commercial broiler farms of Bangladesh related to good farm practices. Microorganisms, 8(11): 1778.

49. Department of Livestock Services. (2010) Ministry of Fisheries and Livestock, Government of the Peoples' Republic of Bangladesh. Fish and Animal Feed Act, Department of Livestock Services, India. p1-9. Available from: http://www.old.dls.gov.bd/files/Animal\%20Feed $\% 20$ Act\%20-2010.pdf. Retrieved on 08-09-2021.

50. Ministry of Fisheries and Livestock (MoFL). (2013) Government of the Peoples' Republic of Bangladesh. Fish and Animal Feed Rule, Ministry of Fisheries and Livestock. p1-49. Available from: https://www.mofl.gov.bd/sites/ default/files/files/mofl.portal.gov.bd/law/61 eacebb edf0_483c_a09f_f9c2fa5de36b/Animal\%20Feed\%20rule2013.pdf. Retrieved on 08-09-2021.

51. Kabir, S.M.L., Sumon, M., Amin, M.M. and Yamasaki, S. (2014) Isolation, identification and antimicrobial resistance patterns of Campylobacter species from broiler meat sold at KR market of Bangladesh Agricultural University Campus, Mymensingh. J. Agric. Food Technol., 4(4): 15-21.

52. Neogi, S.B., Islam, M.M., Islam, S.S., Akhter, A.H.M., Sikder, M.M.H., Yamasaki, S. and Kabir, S.M.L. (2020) Risk of multi-drug resistant Campylobacter spp. and residual antimicrobials at poultry farms and live bird markets in Bangladesh. BMC Infect. Dis., 20(1): 278.

53. Park, J.Y., Kim, S., Oh, J.Y., Kim, H.R., Jang, I., Lee, H.S. and Kwon, Y.K. (2015) Characterization of Clostridium perfringens isolates obtained from 2010 to 2012 from chickens with necrotic enteritis in Korea. Poult. Sci., 94(6): 1158-1164.

54. Diarra, M.S. and Malouin, F. (2014) Antibiotics in Canadian poultry productions and anticipated alternatives. Front. Microbiol., 5(2014): 282.

\section{$* * * * * * * *$}

